\title{
PENERAPAN DATA MINING UNTUK PREDIKSI PENJUALAN ALAT MEDIS MENGGUNAKAN ALGORITMA C4.5 PT. MURNI INDAH SENTOSA
}

\author{
Implementation Of Mining Data For Sales Prediction Of Medical Tools Using C4.5 Algorithm PT. \\ Murni Indah Sentosa
}

\author{
Abdul Fikri ${ }^{1}$, Wiwi Verina ${ }^{2}$ \\ ${ }^{1,2}$ Program Studi Sistem Informasi, Fakultas Teknik dan Ilmu Komputer \\ Universitas Potensi Utama, Jl.K.L. Yos Sudarso KM 6.5 Tanjung Mulia-Medan \\ E-mail : abdulfikri115@gmail.com¹,wiwiverina.azzahra@gmail.com²
}

\section{ABSTRAK}

Alat Medis merupakan perangkat apapun atau peralatan yang bertujuan untuk keperluan para dokter-dokter yang bertugas di rumah sakit maupun klinik. PT. Murti Indah Sentosa perusahaan yang bergerak di bidang penjualan alat medis. Dalam bisnisnya, perusahaan ini sering kali dihadapkan dengan permasalahan menentukan persedian stok alat medis dan tidak dapat mengatasi prediksi penjualan pada periode berikutnya. Sehingga dengan cara seperti ini perusahaan sering kali mengalami kesulitan dalam menentukan persediaan stok alat medis, jadi aplikasi pada sistem yang lama sangat sulit untuk membantu manager dalam menentukan prediksi penjualan untuk priode berikutnya. Tidak jarang stok alat medis yang diminta merupakan stok yang peminatnya kurang dan terjadi penumpukan stok di gudang. Untuk menyelesaikan masalah tersebut dibutuhkan suatu teknologi sistem informasi yang akan membantu manajemen dalam mengelola perusahaan agar setiap keputusan yang diambil ditunjang dengan informasi aktual dan dapat dipercaya. Salah satu teknik yang ada pada data mining adalah klasifikasi dengan algoritma C4.5. Pada penelitian ini akan dibahas teknik klasifikasi yang diterapkan untuk menganalisa data penjualan terutama hal yang berkaitan dengan transaksi penjualan alat medis. Kesimpulan yang diperoleh yaitu dengan menggunakan data mining algoritma C4.5 dapat membantu perusahaan dalam menentukan prediksi penjualan alat medis. Sehingga aplikasi data mining yang dibangun dapat langsung digunakan oleh perusahaan dan dapat dirasakan manfaatnya.

Kata Kunci : Alat Medis, Data Mining, Algoritma C4.5, Prediksi Penjualan

\section{ABSTRACT}

Medical device is any device or equipment that is intended for the needs of doctors who work in hospitals and clinics. PT. Murti Indah Sentosa is a company engaged in the sale of medical devices. In its business, this company is often faced with the problem of determining the stock of medical equipment and cannot overcome the prediction of sales in the next period. So in this way companies often experience difficulties in determining the stock inventory of medical devices, so applications in old systems are very difficult to help managers determine sales predictions for the next period. It is not uncommon for the medical equipment stock that is demanded to be in short supply and there is an accumulation of stock in the warehouse. To solve this problem, an information system technology is needed that will assist management in managing the company so that every decision taken is supported by actual and reliable information. One of the techniques that exist in data mining is the classification with the C4.5 algorithm. This study will discuss the classification techniques applied to analyze sales data, especially those related to medical device sales transactions. The conclusion obtained is that using data mining algorithm C4.5 can help companies in determining predictions of medical device sales. So that the data mining application that is built can be used directly by the company and its benefits can be felt.

Keywords : Medical Devices, Data Mining, C4.5 Algorithm, Sales Prediction 


\section{PENDAHULUAN}

Data mining adalah kegiatan yang meliputi pengumpulan, pemakaian data histori untuk menemukan keteraturan, pola dan hubungan dalam set data berukuran besar. Data mining juga disebut sebagai serangkaian proses untuk menggali nilai tambah berupa pengetahuan yang selama ini tidak di ketahui secara manual dari suatu kumpulan data[1].

PT. Murti Indah Sentosa perusahaan yang bergerak di bidang penjualan alat medis. Dalam bisnisnya, perusahaan ini sering kali dihadapkan dengan permasalahan menentukan persedian stok alat medis dan tidak dapat mengatasi prediksi penjualan pada periode berikutnya. Agar dapat mengasilkan keputusan yang tepat untuk prediksi penjualan alat medis yang sesuai dengan kebutuhan manager dan membantu dibidang penjualan, Maka penulis menggunakan teknik data mining dengan metode C4.5 (Decision Tree) yang sesuai dengan kebutuhan penjualan dan dapat mengatasi penumpukan stok alat medis. Karena dengan menggunakan metode ini data yang digunakan akan diolah sehingga informasi yang tersedia terstruktur kearah pohon keputusan dan mendapatkan pola terbaik.

Metode-metode yang terdapat dalam data mining untuk prediksi diantaranya yaitu C4.5, merupakan algoritma yang digunakan untuk membentuk pohon keputusan. Pohon keputusan merupakan metode klasifikasi dan prediksi yang sangat kuat dan terkenal. Metode pohon keputusan mengubah fakta yang sangat besar menjadi pohon keputusan yang merepresentasikan aturan[2].

Beberapa penulis terdahulu telah menerapkan Data Mining sebagai penelitian dalam menghasilkan sebuah informasi, diantaranya :

Penelitian sebelumnya menjelaskan bahwa penerapan algoritma $\mathrm{C} 4.5$ dalam pilihan bidang peminatan akan membantu dalam pengklasifikasian variable-variabel yang mempengaruhi pemilihan bidang peminatan dan hasil pengujian terhadap pohon keputusan diperoleh kecocokan data $82,14 \%$ terhadap data pemilihan bidang peminatan[3].

Penelitian sebelumnya menjelaskan bahwa menjelaskan bahwa data mining merupakan analisis dari peninjauan kumpulan data untuk menemukan hubungan yang tidak diduga dan meringkas data dengan cara yang berbeda dengan sebelumnya, yang dapat dipahami dan bermanfaat bagi pemilik data[4].

Penelitian sebelumnya menjelaskan bahwa menjelaskan bahwa kriteria-kriteria yang dijadikan patokan dalam memilih suatu kendaraan antara lain, harga, suku cadang, volume silinder, daya jual kendaraan tersebut. Untuk mengolah semua kriteria tersebut diperlukan suatu sistem yang dapat memilih dan mengelompokkan kriteria-kriteria yang dipilih oleh konsumen, sehingga dapat membantu konsumen dalam memilih kendaraan yang paling tepat[5].

Penelitian sebelumnya menjelaskan bahwa berdasarkan data mahasiswa yang diperoleh akan diproses menggunakan data mining untuk membantu penerapan metode Naive Bayes dalam mendapatkan informasi dari hasil klasifikasi kelulusan mahasiswa pada uji kompetisi English Proficiency Test [6].

Penelitian sebelumnya menjelaskan bahwa metode $K$-means dapat diterapkan dalam pengelompokan jumlah wisatawan asing di indonesia dengan jumlah terbanyak dalam setiap bulannya[7].

Penelitian sebelumnya menjelaskan bahwa mulianya tanggung jawab tersebut, BPJamsostek pun terus meningkatkan kompetensi di seluruh lini pelayanan sambil mengembangkan berbagai program dan manfaat yang langsung dapat dinikmati oleh pekerja dan keluarganya.Kini dengan sistem penyelenggaraan yang semakin maju, program BPJamsostek tidak hanya memberikan manfaat kepada pekerja dan pengusaha saja, juga meningkatkan pertumbuhan ekonomi bangsa dan kesejahteraan masyarakat Indonesia[8].

\section{METODOLOGI PENELITIAN}

Dalam mengumpulkan data dan keterangan-keterangan yang dibutuhkan untuk penelitian ini maka penulis menggunakan metode Fish Bone. Berikut ini gambaran dari Fish Bone: 


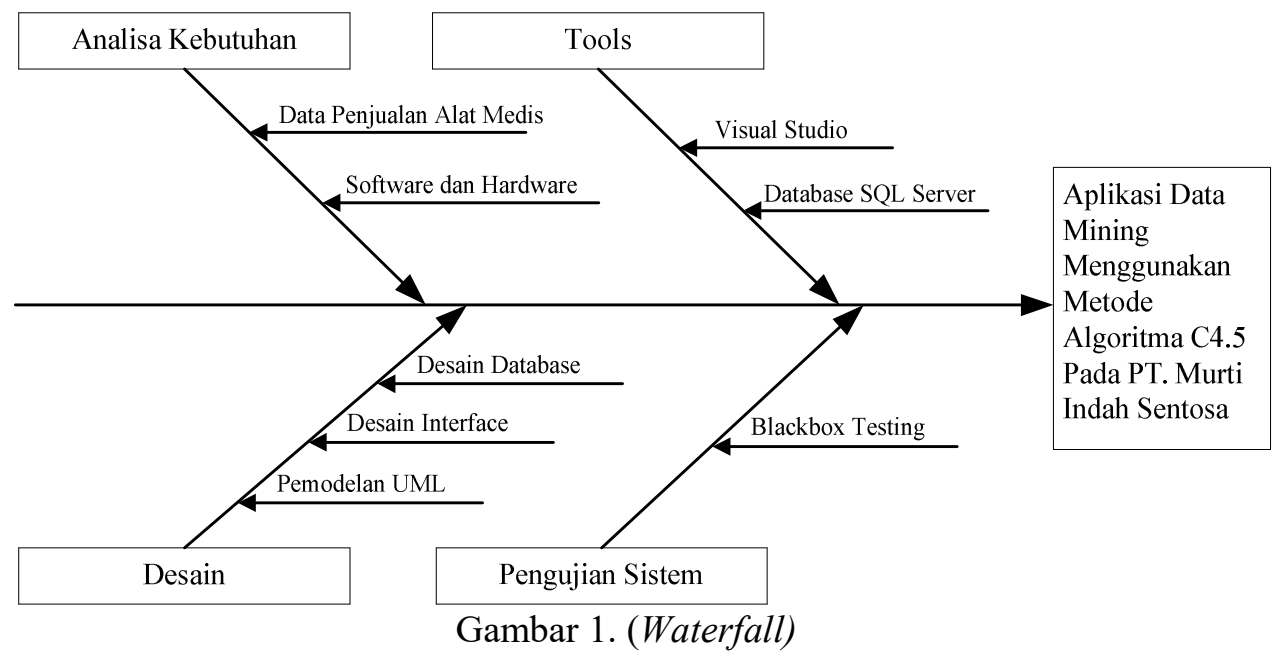

Pengembangan sistem menggunakan fishbone diagram dapat dijelaskan sebagai berikut :

1. Analisa Kebutuhan

Adapun kebutuhan dari sistem yang akan dibangun adalah algoritma C4.5 untuk prediksi stok barang. Pada tahap ini dilakukan pengumpulan data-data teori yang terkait dengan data penjualan alat medis dan mengenai metode C4.5.

2. Desain

Pada tahap ini dilakukan desain perangkat lunak menggunakan pemodelan UML yaitu usecase diagram, class diagram, activity diagram dan seqeunce diagram.

3. Tools

Pada tahap ini untuk pembuatan sistem diimplementasikan ke dalam kode program maka digunakan Visual Studio dan menggunakan Database SQL Server.

4. Pengujian Sistem

Pengujian dilakukan dengan menggunakan blackbox testing. Blackbox testing adalah metode pengujian perangkat lunak yang menguji fungsionalitas aplikasi yang bertentangan dengan struktur internal. Pengujian praktek dilakukan dengan menggunakan aplikasi Microsoft Visual Studio 2010.

5. Hasil

Tahap ini menghasilkan aplikasi data mining untuk memprediksi penjualan alat medis dengan algoritma $\mathrm{C} 4.5$ dan sistem telah berjalan dengan baik.

\section{HASIL DAN PEMBAHASAN}

\subsection{Analisis Masalah}

Pada saat ini PT. Murti Indah mengalami kesulitan dalam menentukan persediaan stok alat medis, jadi aplikasi pada sistem yang lama sangat sulit untuk membantu manager dalam menentukan prediksi penjualan untuk bulan-bulan berikutnya. Tidak jarang stok alat medis yang diminta merupakan stok yang peminatnya kurang dan terjadi penumpukan stok di gudang.

Dari hasil analisis permasalahan tersebut, perlu dirancang ulang aplikasi lama agar dapat memprediksi penjualan alat medis yang sesuai dengan kebutuhan manager dan membantu di bidang penjualan. Perancangan sebuah aplikasi harus dibuat secara matang, supaya tampilannya mudah dipahami dan hasilnya bermanfaat dan memuaskan bagi para pengguna aplikasi. Data Mining adalah suatu metode pengolahan data untuk menemukan pola yang tersembunyi dari data tersebut. Hasil dari pengolahan data dengan metode data mining ini dapat digunakan untuk mengambil keputusan di masa depan.

\subsection{Penerapan Metode}

Decision Tree memiliki dua jenis variabel yaitu variabel input dan variabel ouput (target). Bentuk tabel training yang digunakan dalam penelitian ini adalah : 
Tabel.1. Variabel Decision Tree

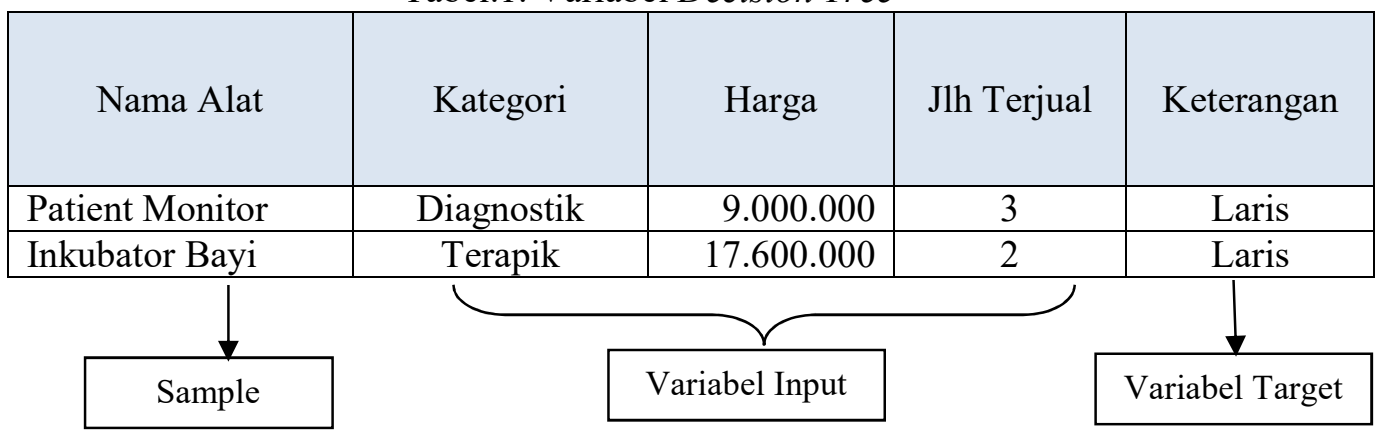

Ujicoba ini bertujuan untuk melakukan perhitungan algoritma untuk mencari variabel terbaik yang akan menjadi pembagi terhadap variabel yang lainnya, dengan menggunakan perhitungan (rumus) Gain Ratio. Decision tree akan dilatihkan terhadap pola data input dan target sebenarnya, seperti terlihat pada tabel berikut ini :

Tabel.2. Data Penjualan Alat Kesehatan

\begin{tabular}{|c|l|c|r|c|}
\hline Tanggal & \multicolumn{1}{|c|}{ Nama Alat } & Kategori & \multicolumn{1}{c|}{ Harga } & $\begin{array}{c}\text { Jlh } \\
\text { Terjual }\end{array}$ \\
& & & & \\
\hline 04-Sep-19 & Patient Monitor & Diagnostik & 9.000 .000 & 3 \\
\hline 04-Sep-19 & Inkubator Bayi & Terapik & 17.600 .000 & 2 \\
\hline 05-Sep-19 & Digital Radiography & Diagnostik & 616.481 .000 & 1 \\
\hline 05-Sep-19 & Elektrokardiograf (EKG) / Alat Rekam Jantung & Diagnostik & 55.000 .000 & 2 \\
\hline 06-Sep-19 & USG General Application & Diagnostik & 605.000 .000 & 1 \\
\hline 06-Sep-19 & Spirometer & Terapik & 9.950 .000 & 2 \\
\hline 09-Sep-19 & Fetal Monitor (Cardiotography) & Diagnostik & 14.300 .000 & 2 \\
\hline 09-Sep-19 & X-Ray Konvensional & Diagnostik & 781.000 .000 & 1 \\
\hline 10-Sep-19 & Inkubator Bayi & Terapi & 9.950 .000 & 2 \\
\hline 13-Sep-19 & Dental & Diagnostik & 33.000 .000 & 3 \\
\hline 13-Sep-19 & Inkubator Bayi & Terapik & 17.600 .000 & 1 \\
\hline 16-Sep-19 & Mesin Anestesi (Anesthesia Machine) & Terapik & 148.464 .000 & 2 \\
\hline 16-Sep-19 & Defibrillator/Alat Pacu Jantung & Terapik & 74.520 .670 & 3 \\
\hline 16-Sep-19 & Survey Meter & Diagnostik & 104.500 .000 & 1 \\
\hline 17-Sep-19 & Fetal Monitor (Cardiotography) & Diagnostik & 14.300 .000 & 1 \\
\hline 17-Sep-19 & USG General Application & Diagnostik & 605.000 .000 & 2 \\
\hline 17-Sep-19 & Hemodialysis & Terapik & 335.000 .000 & 2 \\
\hline 18-Sep-19 & Elektrokardiograf (EKG) / Alat Rekam Jantung & Diagnostik & 55.000 .000 & 2 \\
\hline 18-Sep-19 & Hematology Analyzer & Diagnostik & 100.000 .000 & 3 \\
\hline 19-Sep-19 & Infusion Pump & Terapik & 11.750 .000 & 2 \\
\hline 19-Sep-19 & USG General Application & Diagnostik & 605.000 .000 & 1 \\
\hline 19-Sep-19 & Hemodialysis & Terapik & 335.000 .000 & 2 \\
\hline
\end{tabular}

Untuk lebih memudahkan dalam pembentukan tree maka tabel diatas akan dinormalisasikan lagi. Dengan ketentuan sebagai berikut dibawah ini :

Variabel Harga dibagi 3 golongan yaitu :

a. Jika Harga dibawah Rp. 20.000.000 maka tergolong Murah.

b. Jika Harga Rp. 20.000.000 - Rp. 200.000.000 maka tergolong Mahal.

c. Jika Harga diatas Rp. 200.000.000 maka tergolong Sangat Mahal.

Variabel Jumlah Terjual dibagi 2 golongan yaitu:

a. Jika jumlah terjual hanya $1-2$ unit maka tergolong Sedikit

b. Jika jumlah terjual lebih dari 2 unit maka tergolong Banyak 
Sehingga terbentuk tabel penjualan setelah normalisasi data penjualan sebagai berikut dibawah ini.

Tabel.3. Normalisasi Data Penjualan

\begin{tabular}{|c|c|c|c|c|c|}
\hline No & Nama Alat & Kategori & Harga & $\begin{array}{l}\text { Jlh } \\
\text { Terjual }\end{array}$ & Keterangan \\
\hline 1 & Patient Monitor & Diagnostik & Murah & Banyak & Laris \\
\hline 2 & Inkubator Bayi & Terapik & Murah & Sedikit & Kurang Laris \\
\hline 3 & Digital Radiography & Diagnostik & Sangat Mahal & Sedikit & Kurang Laris \\
\hline 4 & Elektrokardiograf (EKG) / Alat Rekam Jantung & Diagnostik & Mahal & Sedikit & Kurang Laris \\
\hline 5 & USG General Application & Diagnostik & Sangat Mahal & Sedikit & Kurang Laris \\
\hline 6 & Spirometer & Terapik & Murah & Sedikit & Kurang Laris \\
\hline 7 & Fetal Monitor (Cardiotography) & Diagnostik & Murah & Sedikit & Kurang Laris \\
\hline 8 & X-Ray Konvensional & Diagnostik & Sangat Mahal & Sedikit & Kurang Laris \\
\hline 9 & Inkubator Bayi & Terapi & Murah & Sedikit & Kurang Laris \\
\hline 10 & Dental & Diagnostik & Mahal & Banyak & Laris \\
\hline 11 & Inkubator Bayi & Terapik & Murah & Sedikit & Kurang Laris \\
\hline 12 & Mesin Anestesi (Anesthesia Machine) & Terapik & Mahal & Sedikit & Kurang Laris \\
\hline 13 & Defibrillator /Alat Pacu Jantung & Terapik & Mahal & Banyak & Laris \\
\hline 14 & Survey Meter & Diagnostik & Mahal & Sedikit & Kurang Laris \\
\hline 15 & Fetal Monitor (Cardiotography) & Diagnostik & Murah & Sedikit & Kurang Laris \\
\hline 16 & USG General Application & Diagnostik & Sangat Mahal & Sedikit & Kurang Laris \\
\hline 17 & Hemodialysis & Terapik & Sangat Mahal & Sedikit & Kurang Laris \\
\hline 18 & Elektrokardiograf (EKG) / Alat Rekam Jantung & Diagnostik & Mahal & Sedikit & Kurang Laris \\
\hline 19 & Hematology Analyzer & Diagnostik & Mahal & Banyak & Laris \\
\hline 20 & Infusion Pump & Terapik & Murah & Sedikit & Kurang Laris \\
\hline. & $\ldots$ & $\ldots$ & $\ldots$ & & \\
\hline 266 & Computed Radiography & Diagnostik & Sangat Mahal & Sedikit & Kurang Laris \\
\hline
\end{tabular}

Kemudian hitung entropi dengan rumus sebagai berikut :

Keterangan :

$$
\operatorname{Entropi}(S)=\sum_{j=1}^{k}-p_{j} \log _{2} p_{j}
$$

- S adalah himpunan (dataset) kasus

- $\mathrm{k}$ adalah banyaknya partisi $\mathrm{S}$

- $p_{\mathrm{j}}$ adalah probabilitas yang didapat dari Sum(Keterangan) dibagi Total Kasus

Jadi Entropi $(S)=\left(-\left(\frac{35}{226}\right) \times \log _{2}\left(\frac{35}{226}\right)\right)+\left(-\left(\frac{191}{226}\right) \times \log _{2}\left(\frac{191}{226}\right)\right)=0,2116$

Tabel 4. Hasil Perhitungan pada Dataset

\begin{tabular}{|c|c|c|c|}
\hline Total Kasus & Sum (Laris) & Sum (Kurang Laris) & Entropi Total \\
\hline 226 & 35 & 191 & 0,2116 \\
\hline
\end{tabular}

Setelah menghitung entropi total kemudian menghitung entropy pada tiap-tiap variabel kriteria Kategori Produk, entropi Harga dan entropi Jumlah Terjual. Pertama-tama hitung entropi variabel Kategori Produk seperti dibawah ini :

Tabel 5. Nilai Variabel Kategori Produk 


\begin{tabular}{|c|c|c|c|}
\hline Kategori Produk & Keterangan & Jumlah & Total \\
\hline \multirow{2}{*}{ Diagnostik } & Laris $(+)$ & 18 & \multirow{2}{*}{120} \\
\cline { 2 - 3 } & Kurang Laris (-) & 102 & \\
\hline \multirow{2}{*}{ Terapik } & Laris (+) & 17 & \multirow{2}{*}{106} \\
\cline { 2 - 3 } & Kurang Laris (-) & 89 & \\
\hline
\end{tabular}

$\operatorname{Entropy}(S)=\sum_{j=1}^{k}-p_{j} \log _{2} p_{j}$

Variabel Kategori Produk

Entropy $($ Diagnostik $)=-(18 / 120) * \log 2(18 / 120)-(102 / 120) * \log 2(102 / 120)$

$$
=0,6098
$$

Entropy $($ Terapik $)=-(17 / 106) * \log 2(17 / 106)-(89 / 106) * \log 2(89 / 106)$

$$
=0,6352
$$

Lalu Hitung Gain Kategori Produk

Gain $(S$, Kategori $)=$ Entropy $(S)-\sum_{v \text { Diagnosit } k, \text { Terapik }} \frac{\left|S_{v}\right|}{S}$ Entropy $\left(S_{v}\right)$

$=$ Entropy $(S)-\frac{S_{\text {Diagnostik }}}{S}$ Entropy $\left(S_{\text {Diagnostik }} r\right)-\frac{S_{\text {Terapik }}}{S}$ Entropy $\left(S_{\text {terapik }}\right)$

$=(0,2116)-\frac{120}{226}(0,6098)-\frac{106}{226}(0,6352)$

$=0,2116-0,3238-0,2979$

$=-0,4102$

Setelah menghitung entropi Kategori Produk kemudian menghitung entropy pada Harga, seperti dibawah ini:

Tabel 6. Nilai Variabel Harga

\begin{tabular}{|c|c|c|c|}
\hline Harga & Keterangan & Jumlah & Total \\
\hline \multirow{2}{*}{ Murah } & Laris (+) & 24 & \multirow{2}{*}{84} \\
\cline { 2 - 3 } & Kurang Laris (-) & 60 & \multirow{2}{*}{85} \\
\hline \multirow{2}{*}{ Mahal } & Laris (+) & 11 & \multirow{2}{*}{57} \\
\cline { 2 - 3 } & Kurang Laris (-) & 74 & \multicolumn{2}{|c}{} \\
\hline \multirow{2}{*}{ Sangat Mahal } & Laris (+) & 0 & 57 \\
\cline { 2 - 3 } & Kurang Laris (-) & & \\
\hline
\end{tabular}

Variabel Harga

Entropy $($ Murah $)=-(24 / 84) * \log 2(24 / 84)-(60 / 84) * \log 2(60 / 84)$

$$
=0,8631
$$

Entropy $($ Mahal $)=-(11 / 85) * \log 2(11 / 85)-(74 / 85) * \log 2(74 / 85)$

$$
=0,5558
$$

Entropy $($ Sangat Mahal $)=-(0 / 57) * \log 2(0 / 57)-(57 / 57) * \log 2(57 / 57)$

$$
=0
$$

Lalu Hitung Gain Harga

$\operatorname{Gain}(S$, Harga $)=$ Entropy $(S)-\sum_{v \text { Murah , Mahal, SangatMaha }} \frac{\left|S_{v}\right|}{S}$ Entropy $\left(S_{v}\right)$

$=$ Entropy $(S)-\frac{S_{\text {Murah }}}{S}$ Entropy $\left(S_{\text {Murah }}\right)-\frac{S_{\text {Mahal }}}{S}$ Entropy $\left(S_{\text {Mahal }}\right)-\frac{S_{\text {SMahal }}}{S}$ Entropy $\left(S_{\text {SMahal }}\right)$

$=(0,2116)-\frac{84}{226}(0,8631)-\frac{85}{226}(0,5558)-\frac{57}{226}(0)$

$=0,2116-0,3208-0,2090-0$

$=-0,3183$ 
Setelah menghitung entropi Harga kemudian menghitung entropy pada Jumlah Terjual, seperti dibawah ini:

Tabel.7. Nilai Variabel Jumlah Terjual

\begin{tabular}{|c|c|c|c|}
\hline Jumlah Terjual & Keterangan & Jumlah & Total \\
\hline \multirow{2}{*}{ Sedikit } & Laris (+) & 0 & \multirow{2}{*}{191} \\
\cline { 2 - 3 } & Kurang Laris (-) & 191 & \\
\hline \multirow{2}{*}{ Banyak } & Laris (+) & 35 & \multirow{2}{*}{35} \\
\cline { 2 - 3 } & Kurang Laris (-) & 0 & \\
\hline
\end{tabular}

Variabel Jumlah Terjual

Entropy $($ Sedikit $)=-0 / 191) * \log 2(0 / 191)-(191 / 191) * \log 2(191 / 191)$

$$
=0
$$

Entropy $($ Banyak $)=-(35 / 35) * \log 2(35 / 35)-(0 / 35) * \log 2(0 / 35)$

$$
=0
$$

Lalu Hitung Gain Jumlah Terjual

$$
\begin{aligned}
& \text { Gain }(S, \text { JumlahTerj ual })=\text { Entropy }(S)-\sum_{\text {vedikit }, \text { Banyakk }} \frac{\left|S_{v}\right|}{S} \text { Entropy }\left(S_{v}\right) \\
& =\text { Entropy } \quad(S)-\frac{S_{\text {Sedikit }}}{S} \text { Entropy } \quad\left(S_{\text {Sedikit }}\right)-\frac{S_{\text {Banyak }}}{S} \text { Entropy } \quad\left(S_{\text {Banyak }}\right) \\
& =(0,2116)-\frac{191}{226}(0)-\frac{35}{226}(0) \\
& =0,2116-0-0
\end{aligned}
$$

\begin{tabular}{|c|c|c|c|c|c|c|}
\hline Variabel & Nilai & Jlh Data & Laris & $\begin{array}{c}\text { Kurang } \\
\text { Laris }\end{array}$ & Entropi & Gain \\
\hline \multirow{3}{*}{$\begin{array}{l}\text { Kategori } \\
\text { Produk }\end{array}$} & Diagnostik & 120 & 18 & 102 & 0,6098 & \\
\hline & Terapik & 106 & 17 & 89 & 0,6352 & \\
\hline & & & & & & $-0,4102$ \\
\hline \multirow[t]{4}{*}{ Harga } & Murah & 84 & 24 & 60 & 0,8631 & \\
\hline & Mahal & 85 & 11 & 74 & 0,5558 & \\
\hline & Sangat Mahal & 57 & 0 & 57 & 0 & \\
\hline & & & & & & $-0,3183$ \\
\hline \multirow{3}{*}{$\begin{array}{l}\text { Jumlah } \\
\text { Terjual }\end{array}$} & Sedikit & 191 & 0 & 191 & 0 & \\
\hline & Banyak & 35 & 35 & 0 & 0 & \\
\hline & & & & & & 0,2116 \\
\hline
\end{tabular}$$
=0,2116
$$

Tabel.8. Hasil Perhitungan Decision Tree

Karena gain terbesar adalah Gain (Jumlah Terjual). Maka Jumlah Terjual menjadi node akar (root node). Setelah selesai menghitung nilai Gain tiap atribut, maka langkah selanjutnya adalah membuat pohon keputusan. Seperti dibawah ini. 


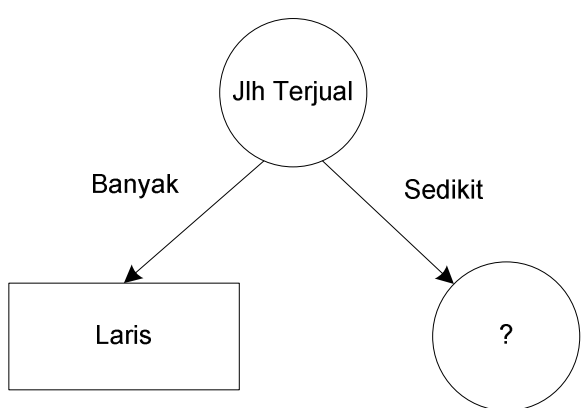

Gambar 2. Pohon Keputusan Node 1 (root node)

Node berikutnya dapat dipilih pada bagian yang mempunyai nilai + dan -, pada kasus diatas keduanya memiliki nilai + dan nilai -. Maka semua pasti mempunyai internal node. Untuk menyusun internal node, ini dilakukan satu persatu.

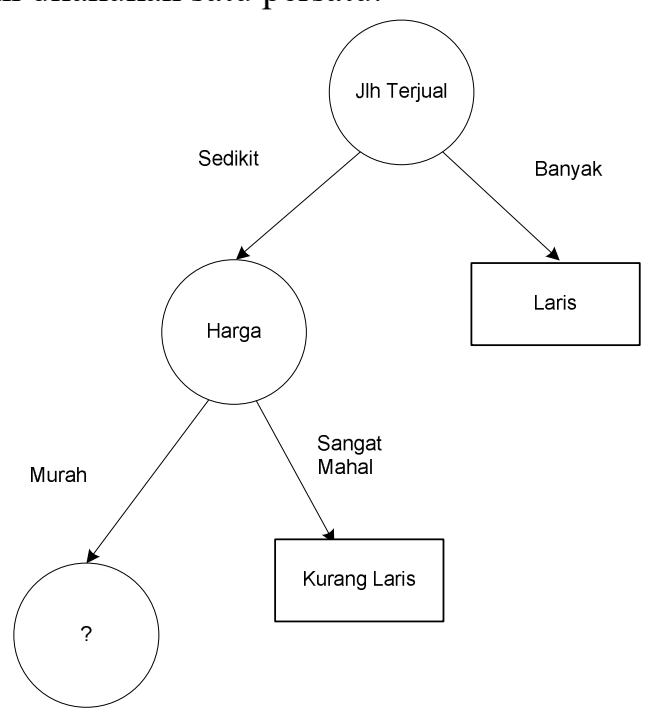

Gambar 3. Pohon Keputusan Node 2 (root selanjutnya)

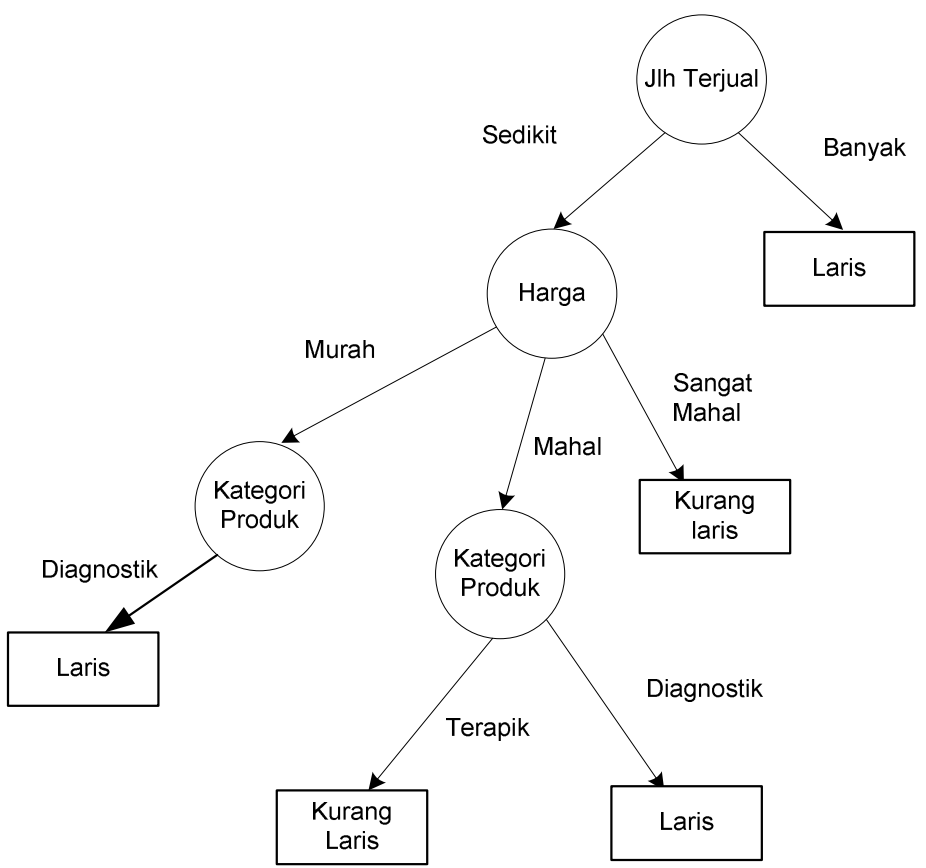

Gambar 4. Pohon Keputusan Akhir 
Dari gambar 4 pohon keputusan akhir, dapat dibentuk rule kesimpulan sebagai berikut :

Rule $1=$ if Jumlah Terjual = Banyak, then keterangan Laris .

Rule 2 = if Jumlah Terjual $=$ Sedikit and Harga $=$ Sangat Mahal, then keterangan Kurang Laris.

Rule $3=$ if Jumlah Terjual $=$ Sedikit and Harga $=$ Mahal and Kategori Produk $=$ Diagnostik, then keterangan Laris.

Rule $4=$ if Jumlah Terjual $=$ Sedikit and Harga $=$ Mahal and Kategori Produk $=$ Terapik, then keterangan Kurang Laris.

Rule $5=$ if Jumlah Terjual $=$ Sedikit and Harga $=$ Murah and Kategori Produk = Diagnostik, then keterangan Laris.

\subsection{Hasil}

Suatu sistem informasi diharapkan mampu menyediakan informasi yang berguna dan berkualitas. Informasi yang berguna dapat dinilai dari ketepatan waktunya dan relevasi dari informasinya. Untuk ketepatan waktu, suatu sistem informasi diharapkan dapat menyediakan informasi yang dibutuhkan secepat mungkin. Adapun hasil dari Penerapan data mining algoritma C4.5 pada PT. Murti Indah Sentosa seperti yang diuraikan dibawah ini.

\section{Tampilan Form Login}

Pada saat program aktif maka akan tampil Form Login yang menganjurkan untuk memasukkan nama dan password untuk masuk kedalam menu utama. Form ini menampilkan Username dan Password.

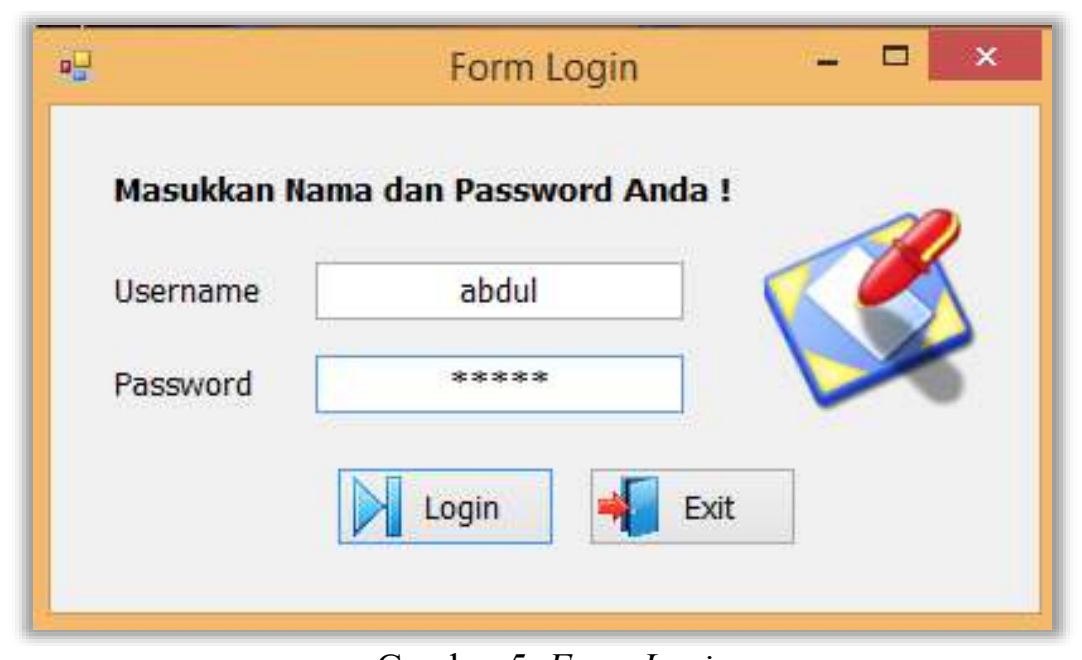

Gambar 5. Form Login

2. Tampilan Menu Utama 


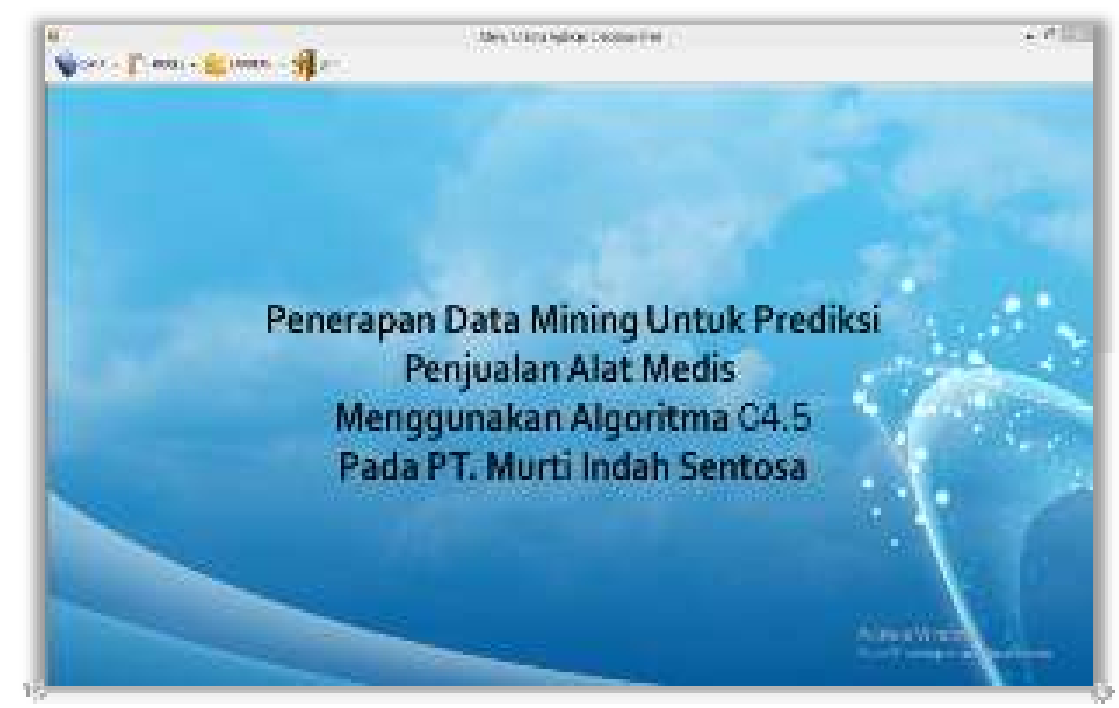

Gambar 6. Form Menu Utama 
3. Tampilan Form Data Produk

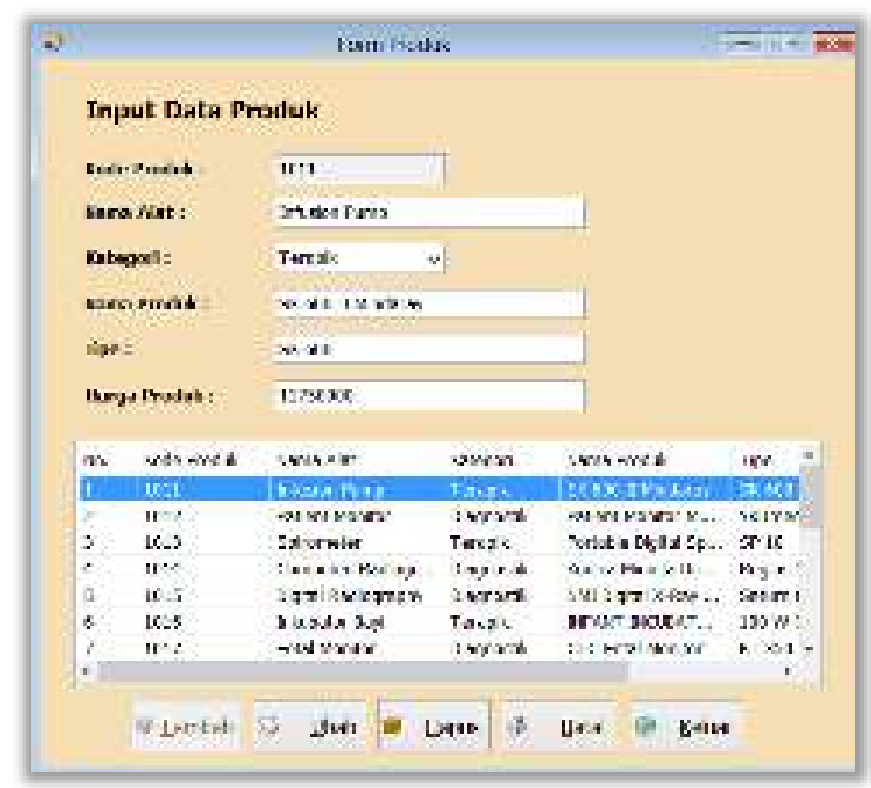

Gambar 7. Form Data Produk

4. Tampilan Form Penjualan

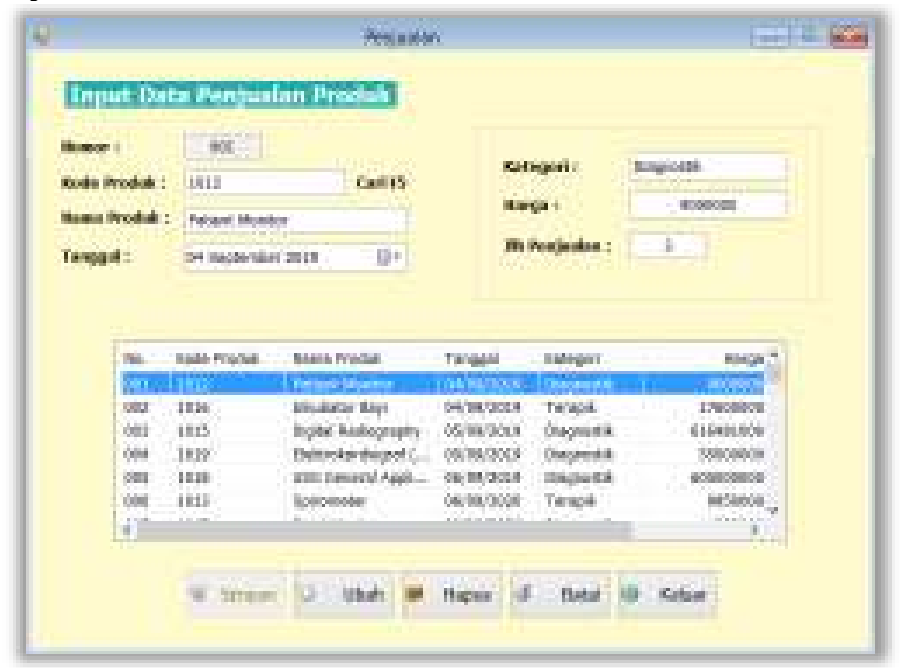

Gambar 8. Form Penjualan

5. Tampilan Form Proses Decision Tree

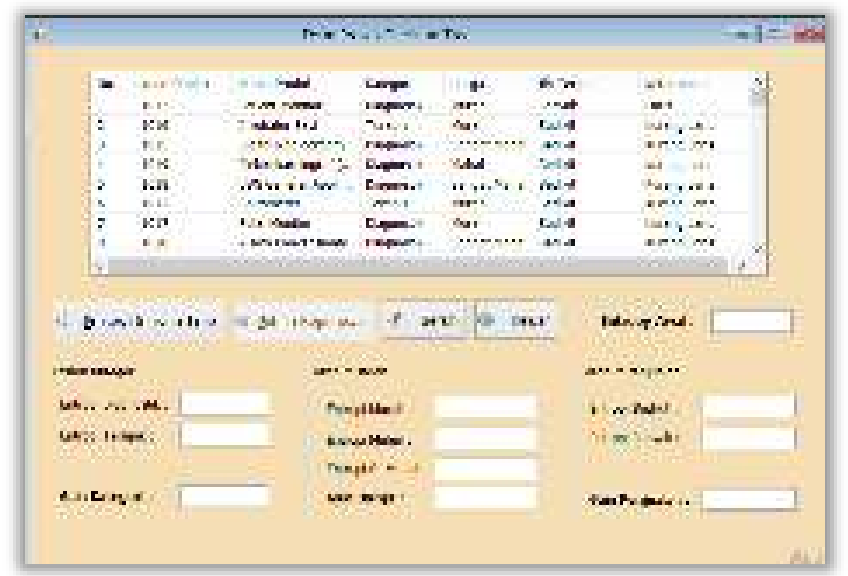

Gambar 9. Form Proses Decision Tree 


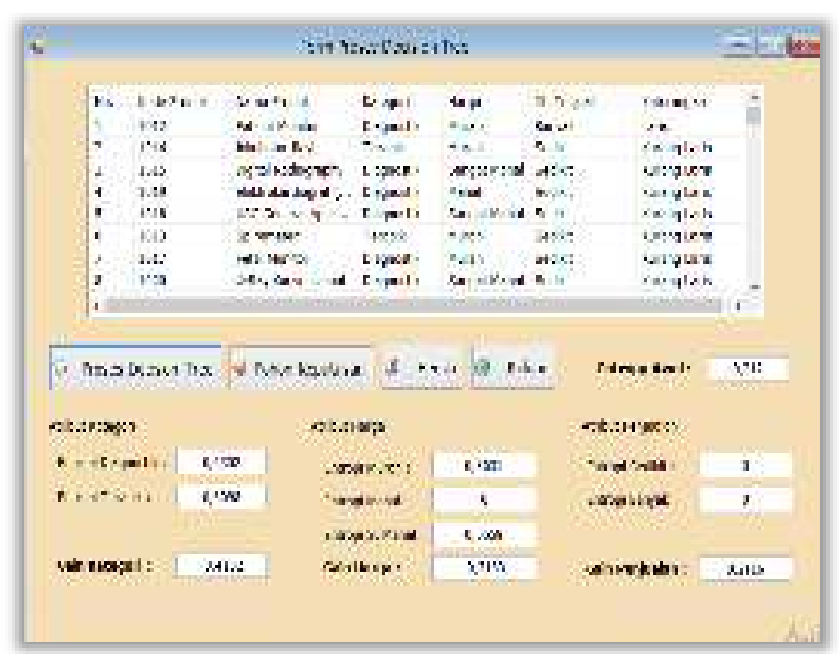

Gambar 10. Tampilan Hasil Form Proses Decision Tree

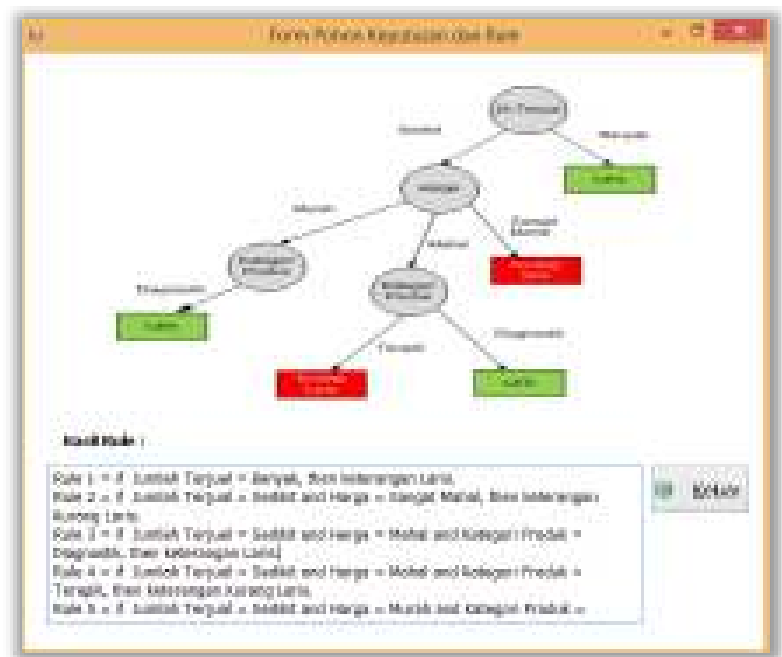

Gambar 11. Tampilan Hasil Pohon Keputusan dan Rule

6. Tampilan Laporan Penjualan

\begin{tabular}{|c|c|c|c|c|c|}
\hline \multicolumn{6}{|c|}{ 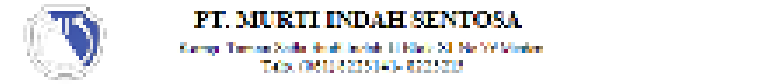 } \\
\hline \multicolumn{6}{|c|}{ Larokaxraxrdedsrocotx } \\
\hline 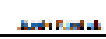 & phenosis & meates & Aage & metes & . Anere \\
\hline$n$ & noweaves:s & $\operatorname{suc} 4 x$ & is $\mathrm{x}=\mathrm{men}$ & tene & 2 \\
\hline wh & sinimeter & Tenes & Bs Than & an & 2 \\
\hline Wt & 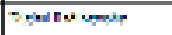 & mopost & Av roun & Fate & $\bar{*}$ \\
\hline ze? & 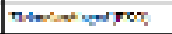 & Nheows & s. $\quad n=m$ & 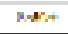 & 2 \\
\hline sa & avaseve: :2:0 & wasedic & (2) isomims & $2 n c=$ & - \\
\hline 30 & idiocse & leose & is socum & sece & 2 \\
\hline $\bar{T}$ & $\operatorname{mon} x$ & nenews & 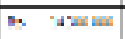 & atio & $?$ \\
\hline 'wes & Thenmon w & repoust & os $v=m$ & wot & $\cdot$ \\
\hline$=1$ & Nutwern:y & Trepe & c) $\cdot 2 \times=$ & 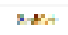 & $=$ \\
\hline$x$ & cenve & vactes & is & ienc & 2 \\
\hline st & 3 simesenter & Tente & 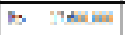 & wie & 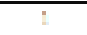 \\
\hline $\bar{m}$ & Vaniand & $\operatorname{tams}$ & 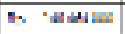 & ratio & 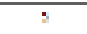 \\
\hline is & 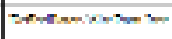 & $\operatorname{tans}$ & 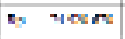 & $n \rightarrow \infty$ & 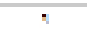 \\
\hline$m$ & $\cos 2 x$ & Paysuas & c, wem & 320 & $:$ \\
\hline 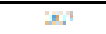 & $2 n \cdot i=s y$ & censis & is sieum & skec & 2 \\
\hline "rs & 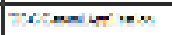 & recurb & Ds diswad & asio & $?$ \\
\hline$\cdot m$ & ravkintis & $7 m b$ & n. minz & 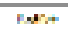 & 9 \\
\hline
\end{tabular}

Gambar 12. Tampilan Laporan Penjualan 


\subsection{Perangkat Keras}

Perangkat keras yang dibutuhkan yaitu:

1. CPU minimal setara Intel Core i3

2. Hardisk 320 Gigabyte

3. Memory $1 \mathrm{GHz}$

4. VGA $512 \mathrm{MHz}$

5. Flashdisk, DVD Room, Monitor, Keyboard Mouse dan Printer.

\subsection{Perangkat Lunak}

Perangkat lunak yang dibutuhkan yaitu:

1. Microsoft SQL Server 2008

2. Microsoft Visual Studio 2010

3. Seagate Crystal Report 13

\section{KESIMPULAN}

Setelah melakukan berbagai macam tahapan-tahapan maka diperoleh suatu kesimpulan sebagai berikut:

1. Dengan menggunakan data mining algoritma C4.5 ini maka pegawai pada PT. Murti Indah Sentosa dapat mendokumentasikan dan menyimpan data penjualan dengan baik di dalam database dengan cepat, sehingga memudahkan pekerjaan dalam pengolahan data di bidang penjualan alat medis.

2. Dengan adanya implementasi data mining algoritma C4.5 ini, pegawai di PT. Murti Indah Sentosa telah terbantu dalam memprediksi kategori alat medis yang laris serta menghasilkan output berupa laporan penjualan dan gambar pohon keputusan yang dapat dilakukan dengan cepat.

3. Dengan menggunakan aplikasi yang dirancang ini dapat memecahkan masalah yang dihadapi oleh PT. Murti Indah Sentosa yakni masalah dalam hal memprediksi penjualan alat medis. Dengan diterapkannya sistem ini segala kendala tentang keterlambatan dan kesalahan laporan-laporan yang berhubungan dengan masalah penjualan alat medis dapat diatasi dengan efektif dan efesien.

4. Program yang dirancang merupakan merupakan penyempurnaan dari sistem yang ada dan dapat membantu pihak perusahaan dalam mengatur data penjualan alat medis secara efisien.

\section{SARAN}

Adapun saran-saran yang dapat disampaikan kepada PT. Murti Indah Sentosa dan kepada seluruh pihak yang berkaitan dengan perancangan sistem ini, yaitu :

1. Program yang dibuat ini masih dapat dikembangkan lebih lanjut supaya menjadi sistem yang lebih lengkap berdasarkan dengan kepentingan yang lebih luas. Hal yang dapat dikembangkan antara lain adalah penambahan jumlah atribut/variabel hingga tidak ada batasannya dan penambahan jumlah data bisa dilakukan berdasarkan ketentuan-ketentuan dari perusahaan yang dipakai sebagai variabel pembanding.

2. Program data mining memprediksi penjualan alat medis dengan metode decision tree algoritma C4.5 belum memiliki metode pembanding lainnya, seperti metode clustering atau yang lainnya.

3. Program aplikasi data mining dengan algoritma C4.5 ini belum bisa di update secara online. Sehingga harus langsung ke komputer untuk melakukan update.

\section{UCAPAN TERIMA KASIH}

Penulis mengucapkan terima kasih kepada pihak Universitas Potensi Utama yang telah membantu penulis dalam penelitian ini. 


\section{DAFTAR PUSTAKA}

[1] Kamal, I. M., \& Ilyas, R. (2017). PREDIKSI PENJUALAN BUKU MENGGUNAKAN DATA MINING DI PT. NIAGA SWADAYA. SEMNASTEKNOMEDIA ONLINE, 5(1), 2-1.

[2] Eska, J. (2018). Penerapan Data Mining Untuk Prediksi Penjualan Wallpaper Menggunakan Algoritma C4. 5.

[3] Nasari, F. (2017, October). Penerapan Algoritma C4. 5 dalam Pemilihan Bidang Peminatan Program Studi Sistem Informasi di Stmik Potensi Utama Medan. In Seminar Nasional Informatika (SNIf) (Vol. 1, No. 1, pp. 30-34).

[4] Yunus, M., Dachlan, H. S., \& Santoso, P. B. (2014). SPK Pemilihan Calon Pendonor Darah Potensial dengan Algoritma C4. 5 dan Fuzzy Tahani. Jurnal EECCIS, 8(1), 47-54.

[5] Harahap, F. (2018). Penerapan data Mining dalam Pemilihan Mobil menggunakan Algoritma C4. 5. Jurnal VOI (Voice Of Informatics), 7(1).

[6] Saleh, A. (2015). Penerapan Data Mining Dengan Metode Klasifikasi Naïve Bayes Untuk Memprediksi Kelulusan Mahasiswa Dalam Mengikuti English Proficiency Test. no. February, 2016.

[7] Darrma, S., Defit, S., Hartama, D., Robiansyah, W., \& Firzada, F. (2020, July). Penerapan Metode K-Means Dalam Pengolompokan Jumlah Wisatawan Asing Di Indonesia. In Prosiding Seminar Nasional Riset Information Science (SENARIS) (Vol. 2, pp. 255-261).

[8] Nasution, R. S., Verina, W., \& Tanjung, M. R. (2020). Rancang Bangun Aplikasi Pemilihan Pegawai Berprestasi Dengan Metode Profile Matching Berbasis Android Pada BPJS Ketenagakerjaan. Jurnal Mahasiswa Fakultas Teknik dan Ilmu Komputer, 1(1), 666-680.

[9] Cynthia, E. P., \& Ismanto, E. (2018). Metode Decision Tree Algoritma C. 45 Dalam Mengklasifikasi Data Penjualan Bisnis Gerai Makanan Cepat Saji. Jurasik (Jurnal Riset Sistem Informasi dan Teknik Informatika), 3, 1-13.

[10] Amalia, Y. R. (2018). Penerapan Data Mining Untuk Prediksi Penjualan Produk Elektronik Terlaris Menggunakan Metode K-Nearest Neighbor (Studi Kasus: PT. Bintang Multi Sarana Palembang) (Doctoral dissertation, UIN RADEN FATAH PALEMBANG). 